\title{
Penerapan Model Pembelajaran Picture and Picture Berbantu Media Audio Visual Berbasis Animasi Flash untuk Meningkatkan Keterampilan Menulis Karangan Cerita
}

\author{
Denis Yulian Alfianto ${ }^{1 *}$ \\ ${ }^{1}$ Fakultas Ilmu Pendidikan, Universitas PGRI Semarang, Indonesia
}

\section{A R T I C L E I N F O}

Article history:

Received 19 September 2020

Received in revised form 30 November 2020

Accepted 05 January 2021

Available online 11

February 2021

Kata Kunci:

Keterampilan Menulis

Karangan Sederhana,

Model Pembelajaran

Picture and Picture

Keywords:

Writing Skills, Simple

Writing, Picture and

Picture Learning Model.

\begin{abstract}
A B S T R A K
Keterampilan menulis di sekolah dasar masih sangat rendah hal ini disebabkan oleh penerapn model pembelajaran yang monoton serta pengunaan media yang tidak efektif. Peneliti ingin bertujuan untuk mengkaji efektivitas model pembelajaran kooperatif tipe Picture and Picture berbasis video animasi flash untuk meningkatkan keterampilan menulis karangan siswa. Jenis penelitian ini adalah penelitian tindakan kelas.. Subjek penelitian ini adalah siswa kelas III SDN yang berjumlah 15 siswa.Pengumpulan data dalam penelitian ini menggunakan tes dan observasi. Teknik analisis data berupa analisis deskriptif kualitatif dan kuantitatif. Hasil penelitian ini menunjukkan bahwa pada pra siklus jumlah siswa yang mencapai KKM hanya 4 siswa atau $26,70 \%$. Jumlah siswa yang mencapai KKM meningkat pada siklus I yaitu mencapai 10 siswa atau sebesar $66,70 \%$ dan kembali meningkat pada siklus II yaitu mencapai 14 siswa atau 93,33\%. Jumlah peningkatan siswa yang mencapai KKM pada pra siklus dan siklus II meningkat sebanyak 10 siswa atau $66,70 \%$. Hasil observasi menunjukkan bahwa proses pembelajaran di kelas juga meningkat. Hal tersebut ditunjukkan dengan siswa lebih bersemangat, antusias, dan aktif dalam mengikuti pembelajaran menulis. Selain itu, siswa juga menjadi lebih termotivasi untuk menulis karangan.
\end{abstract}

A B S T R A K

Writing skills in elementary schools are still very low, this is due to the application of a monotonous learning model and ineffective use of media. The researcher aims to examine the effectiveness of the Picture and Picture type of cooperative learning model based on flash animation video to improve students' essay writing skills. This type of research is classroom action research. The subjects of this study were 15 grade students of SDN. Collecting data in this study used tests and observations. The data analysis technique was in the form of qualitative and quantitative descriptive analysis. The results of this study indicate that in the pre-cycle the number of students who reached the KKM was only 4 students or $26.70 \%$. The number of students who reached the KKM increased in the first cycle, reaching 10 students or $66.70 \%$ and again increasing in the second cycle, reaching 14 students or $93.33 \%$. The increase in the number of students who reached the KKM in the pre-cycle and cycle II increased by 10 students or $66.70 \%$. The results of the observations show that the learning process in the classroom also improves. This is shown by the students being more enthusiastic, enthusiastic, and active in participating in writing learning. In addition, students become more motivated to write essays.

\section{Pendahuluan}

Keterampilan Bahasa Indonesia terdiri atas keterampilan menyimak, keterampilan berbicara, keterampilan berbicar, keterampilan menulis dan keterampilan membaca (Hasmi, 2017). Salah satu 
keterampilan Bahasa adalah keterampilan menulis. Keterampilan menulis merupakan salah satu keterampilan berbahasa yang bermanfaat bagi kehidupan manusia, khususnya para siswa (Yesica \& Rosmaini, 2017). Keterampilan menulis akan memudahkan seseorang untuk mengkomunikasikan gagasan, ide, pikiran, dan pengalamannya ke berbagai pihak (Ahmad, 2016). Keterampilan menulis dapat dikatakan sulit karena menulis dalam prosesnya menggunakan kedua belahan otak (Dalman, 2017). Menulis adalah proses mengait-ngaitkan antara kata, kalimat, paragraf maupun antara bab secara logis agar dapat dipahami. Proses ini mendorong seorang penulis harus berpikir secara sistematis dan logis sekaligus kreatif. Keterampilan ini berkaitan dengan kegiatan siswa dalam memilih, memilah, dan menyusun pesan untuk disampaikan melalui bahasa tulis sehingga pesan yang akan disampaikan dan diungkapkan dapat mudah dipahami orang lain. Melalui proses menulis dapat membantu siswa untuk mengabadikan ide dan gagasannya, yang berkaitan erat dengan keterbatasan memori manusia yang tidak dapat mengingat semua hal. Disamping itu, proses menulis ini sangatlah penting sebagai salah satu bentuk komunikasi yaitu komunikasi tertulis. Komunikasi lisan dengan segala keterbatasannya dapat dibantu oleh komunikasi tertulis yang dapat dibaca lagi dikemudian hari apabila dibutuhkan. Oleh karena itu, sangatlah penting dan bermanfaat keterampilan menulis bagi seluruh manusia terlebih siswa sekolah dasar dalam dunia pendidikan.

Namun untuk melakukan kegiatan menulis ini, tidak semua orang mudah melakukannya. Banyak yang mengalami kesulitan pada saat hendak menulis. Terkadang sebagian orang merasa tidak ada ide/gagasan yang akan ditulis, merasa tidak bisa, takut, atau pikiran negatif lainnya yang dapat menghambat kegiatan menulis. Masalah tersebut juga peneliti temukan pada siswa kelas III SDN Kalipucang Wetan. Dari hasil penelitian di temukan Permasalahan dalam pembelajaran yang diantaranya adalah sikap siswa yang kurang memperhatikan pada saat pembelajaran, kurang adanya motivasi belajar beberapa siswa dalam mengikuti pembelajaran, juga rendahnya kemampuan beberapa siswa dalam menerima materi pelajaran. Masalah-masalah tersebut juga berpengaruh terhadap hasil belajar siswa, sehingga terdapat beberapa nilai mata pelajaran yang rendah salah satunya yaitu dalam mata pelajaran bahasa Indonesia. Masalah-masalah yang dikemukakan juga terlihat pada saat observasi yang dilakukan pada saat pembelajaran di kelas. Hasil observasi menunjukkan bahwa terdapat beberapa kendala yang terlihat pada saat berlangsungnya pembelajaran di kelas. Kendala tersebut diantaranya adalah terdapat beberapa siswa yang ramai sendiri, serta terdapat pula beberapa siswa yang hanya diam saja pada saat pembelajaran. Beberapa siswa yang ramai sendiri menyebabkan konsentrasi siswa yang lain terganggu dalam mengikuti pembelajaran. Selain itu, siswa yang hanya diam saja pada saat pembelajaran menunjukkan siswa kurang memiliki semangat dan motivasi dalam mengikuti pembelajaran. Hal itu terlihat dari beberapa siswa yang diam saja pada saat pembelajaran akan tetapi tidak memperhatikan penjelasan dari guru. Berdasarkan hasil observasi dalam pembelajaran bahasa Indonesia di kelas III, menunjukkan bahwa keterampilan menulis karangan siswa kelas III masih rendah. Hal tersebut dibuktikan dengan banyaknya hasil mengarang siswa yang mendapat nilai di bawah KKM, hampir 75\% siswa mendapat nilai di bawah KKM dan hanya sekitar 25\% siswa yang mendapat nilai di atas KKM. Disamping rendahnya nilai hasil mengarang siswa, dalam proses pembelajaran menulis karangan juga terlihat beberapa siswa kesulitan dalam membuat karangan. Hal tersebut ditunjukkan dengan adanya beberapa siswa yang belum menyelesaikan tugasnya pada akhir pembelajaran, siswa meminta waktu tambahan kepada guru untuk menyelesaikan hasil karangannya. Pada saat kegiatan menulis, terlihat juga beberapa siswa yang melihat pekerjaan teman lainnya. Selain itu terdapat pula pertanyaan siswa yang menanyakan "Apakah hasil karangan boleh sama dengan teman sebangkunya?".

Masalah selanjutnya yang ditemukan dalam sebagian besar karangan siswa adalah masalah penggunaan bahasa. Bahasa yang dipilih sebagian siswa adalah bahasa yang tidak baku. Ditemukan beberapa kalimat tidak baku dalam sebagian karangan siswa. Selain bahasa yang tidak baku, terkadang terdapat beberapa kalimat yang menggunakan bahasa daerah. Terkadang siswa sulit untuk mengungkapkan kata yang diinginkan dalam bahasa Indonesia sehingga menuliskan dalam bahasa tidak baku atau bahasa daerahnya.

Selain kesalahan-kesalahan di atas, ditemukan pula dalam karangan beberapa siswa yang membuat kesalahan dalam penulisan beberapa kosa kata. Kesalahan yang ditemukan seperti huruf dalam kata yang kurang lengkap atau penggunaan huruf yang tidak tepat. Kemampuan merangkai kata-kata menjadi suatu kalimat dan paragraf yang padu pun masih kurang. Terlebih dalam penggunaan konjungsi, sebagian siswa kurang tepat dalam menggunakan konjungsi untuk menyambungkan kata atau kalimat. Sebab lain rendahnya keterampilan menulis karangan siswa rendah adalah metode dan model pembelajaran yang diterapkan guru kurang bervariasi. Guru menerapkan metode ceramah dalam menjelaskan materi, kemudian dilanjutkan dengan memberi contoh teks. Menurut peneliti, metode tersebut kurang menarik perhatian siswa. Terlebih bagi siswa kelas III yang masih dalam masa transisi dari kelas rendah menuju kelas atas. Siswa kelas III masih asyik dengan dunia bermain antarteman 
sebaya. Siswa masih menyukai kegiatan yang melibatkan temannya, sehingga siswa tidak cepat bosan selama pembelajaran. Oleh karena itu, siswa masih membutuhkan kegiatan pembelajaran yang melibatkan dirinya serta teman- temannya.

Model picture and picture melatih siswa untuk berpikir logis dan sistematis. Membantu siswa belajar berpikir berdasarkan sudut pandang suatu subjek bahasan dengan memberikan kebebasan siswa beragumen terhadap gambar yang diperlihatkan (Heriyanto, 2014; Susanti \& Kusmariyani, 2017). Selain itu, dapat memunculkan motivasi belajar siswa kearah yang lebih baik. Model pembelajaran picture and picture dapat meningkatkan minat siswa dalam proses pembelajaran (Pangestu et al., 2019). Pembelajaran ini memiliki ciri Aktif, Inovatif, Kreatif, dan Menyenangkan. Pembelajaran picture and picture ini siswa dituntut harus bertanggung jawab atas segala sesuatu yang dikerjakan dalam kelompoknya (Pebriana et al., 2017). Menggunakan alat bantu media gambar tersebut diharapkan siswa dapat mengikuti pelajaran dengan fokus yang baik dan dalam kondisi yang menyenangkan, sehingga apapun pesan yang disampaikan oleh guru, bisa diterima dengan baik dan mampu meresap dalam hati serta dapat diingat kembali oleh siswa (Telussa, 2017). Model pembelajaran picture and picture dalam meningkatkan kemampuan menulis teks recount. Jadi, model pembelajaran picture and picture sangat efektif dalam meningkatkan kemampuan menulis (Widyawati, 2019). Pembelajaran Picture and Picture dapat meningkatkan hasil belajar siswa, tetapi semua itu kembali pada guru, siswa itu sendari jika guru mengajar sesuai dengan tujuan pembelajaran maka akan mendapat hasil yang baik pula, tetapi jika siswanya tidak mendukung hal itu maka tujuan pembelajaran tidak akan tercapai (St. \& Saliadin, 2016). Jika siswa memiliki tingkat intellengensi yang tinggi maka tujuan pembelajaran akan tercapai. Jadi, penerapan model picture and picture akan membuat siswa belajar lebih giat karena siswa dapat melihat dan paham akan materi karena materi yang bersifat abstrak bisa dilihat secara nyata oleh siswa. Selain model pembelajaran media juga bisa digunakan sebagai solusi pembelajaran. dalam penelitian ini media yang digunakan dalam penelitian ini adalah media audio visual berbasis animasi Flash.

Media audio visual yang menampilkan realitas materi dapat memberikan pengalaman nyata pada siswa saat mempelajarinya sehingga mendorong adanya aktivitas diri (Utami et al., 2019). Media audio visual berupa video dapat menyajikan masalah atau materi yang dapat menarik perhatian dan minat siswa dalam mengikuti pembelajaran di dalam kelas (Agustini et al., 2016). Media audio visual memiliki potensi yang cukup besar bila dimanfaatkan sebagai media pembelajaran yang memungkinkan peserta didik akan dapat mengamati secara langsung tentang wujud benda yang sesungguhnya, mengamati proses dari suatu kejadian atau suatu perubahan, mengamati perbedaan warna dan mengamati suatu gerakan dan lain-lain yang diiringi beserta dengan suara (Israwati, 2017). Media audio visual akan membuat siswa lebih aktif dan pembelajaran lebih bermakna karena model pembelajaran yang menitikberatkan pada penggunaan masalah di dunia nyata yang melibatkan siswa untuk memecahkan masalah tersebut (Kusumayanti et al., 2017; Paramartha et al., 2016). Media audio visual membantu menampilan fakta atau konsep secara nyata sehingga siswa lebih mudah untuk memahami pembelajaran yang diberikan, dengan pemahaman yang lebih baik maka hasil belajarpun akan lebih baik pula (Windasari \& Sofyan, 2018). Salah satu media audio visual adalah animasi flash.

Media animasi Flash karena Flash merupakan sebuah program yang mampu membuat Animasi mulai dari yang sederhana hingga kompleks (Hartiti, 2014). Media animasi berbasis macromedia flash sudah banyak digunakan untuk meningkatkan hasil belajar dan membuktikan bahwa media animasi dapat meningkatkan hasil belajar kognitif, afektif dan psikomotorik siswa(Abu \& Hamsyah, 2016; Agustina et al., 2017; Sukiyasa \& Sukoco, 2013). Animasi Flash cenderung di buat dengan Adobe Flash atau software yang sejenis. Konsep Animasi flash sangat mirip dengan video, dikarenakan dia terdiri dari urutan gambargambar statis untuk menciptakan ilusi seolah-olah adanya gerakan disaat gambar-gambar tersebut di mainkan secara berurutan dengan sukses. Banyak sekali projek multimedia yang menggunakan film animasi, termasuk Animasi flash, dan software untuk merakit film animasi tersebut. Menggunakan model pembelajaran kooperatif tipe Picture and Picture berbasis video animasi flash tersebut siswa dapat lebih mengembangkan keterampilan menulis siswa. Melalui model Picture and Picture berbasis video animasi flash dapat memudahkan siswa dalam membuat alur suatu karangan. Melalui model pembelajaran kooperatif siswa dapat mengembangkan potensi individu dan dapat pula saling membantu dan bekerjasama dalam kelompok kecil. Oleh karena itu, peneliti ingin bertujuan untuk mengkaji efektivitas model pembelajaran kooperatif tipe Picture and Picture berbasis video animasi flash di kelas III SDN Kalipucang Wetan untuk meningkatkan keterampilan menulis karangan siswa.

\section{Metode}

Penelitian dilaksanakan di SDN Kalipucang Wetan yang terletak di Jalan Mataram II No 31 Kalipucang Wetan Kecamatan Batang Kabupaten Batang. Pemilihan tempat didasarkan pada 
pertimbangan masalah yang ditemukan di SDN Kalipucang Wetan. Ditemukan permasalahan mengenai rendahnya keterampilan menulis siswa kelas III dalam mata pelajaran Bahasa Indonesia. Penelitian ini dilaksanakan dari bulan September hingga Desember 2020. Penelitian dilaksanakan pada tahun ajaran 2020/2021 semester I, karena sesuai dengan waktu materi menulis karangan cerita sederhana diajarkan bagi kelas III sekolah dasar. Subjek penelitian dalam penelitian ini adalah siswa di SDN Kalipucang Wetan. Subjek penelitian siswa dalam penelitian ini adalah siswa kelas III SDN Kalipucang Wetan yang berjumlah 15 siswa, yang terdiri dari 8 perempuan dan 7 laki-laki. Mata pelajaran yang diteliti adalah Bahasa Indonesia. Objek penelitian dalam penelitian ini adalah proses dan hasil dalam pembelajaran bahasa Indonesia di kelas III SDN Kalipucang Wetan dengan menggunakan model pembelajaran kooperatif tipe Picture and Picture berbantu media audio visual berbasis Animasi Flash. Penelitian ini menggunakan Penelitian Tindakan Kelas.Model ini membagi prosedur penelitian kegiatan pada satu putaran (siklus), yaitu: Perencanaan, pelaksanaan, observasi, evaluasi, dan refleksi. Siklus ini dilakukan secara terusmenerus dan berkesinambungan sampai indikator keberhasilan tindakan telah tercapai. Instrumen penelitian adalah alat yang dapat digunakan untuk mengumpulkan data penelitian. Bentuk instrumen yang digunakan dalam penelitian adalah sebagai berikut: 1) Lembar Observasi, Observasi dalam penelitian ini dilakukan pada saat proses pembelajaran sedang berlangsung saat pelaksanaan model pembelajaran kooperatif Picture and Picture. Hasil observasi dicatat dalam lembar observasi yang telah disediakan. Observasi ini dilakukan dengan tujuan untuk memperoleh data partisipasi keterlibatan siswa selama pembelajaran berlangsung dan pengaruh dalam pelaksanaan model pembelajaran kooperatif tipe Picture and Picture dalam pembelajaran. Lembar observasi dalam penelitian ini terdiri dari lembar observasi guru dan lembar observasi siswa; 2) Tes Menulis, Tes menulis dalam penelitian ini dilakukan untuk mengetahui perubahan keterampilan menulis siswa sebelum dan sesudah melaksanakan model pembelajaran tipe Picture and Picture berbantu media audio visual berbasis video animasi flash dalam pembelajaran, Teknik analisis data yang digunakan dalam penelitian ini adalah deskriptif kualitatif untuk data lembar observasi siswa dan guru, serta deskriptif kuantitatif untuk mengukur tingkat keterampilan menulis karangan siswa dengan membandingkan hasil nilai sebelum dan sesudah tindakan.

\section{Hasil dan Pembahasan}

Dalam pembelajaran menulis karangan sederhana pada tahap ini, guru menyampaikan beberapa materi tentang materi gambar seri yang ada pada buku paket siswa. Guru memberi contoh gambar dan video animasi flash lalu membahas bersama-sama dengan siswa terkait dengan urutan gambar dan video animasi flash dan beberapa kalimat yang mendukung gambar dan video animasi flash. Tahap selanjutnya siswa diminta untuk membuat karangan sederhana berdasarkan gambar seri acak yang ada di buku paket.

Berdasarkan hasil tes awal menulis karangan sederhana diperoleh nilai rata- rata karangan sederhana siswa yaitu 59,67. Ketuntasan siswa dilihat dari perolehan nilai siswa yang lebih dari KKM yaitu 68. Jumlah siswa yang mendapat nilai lebih dari KKM adalah 4 (26,7\%) siswa, sedangkan jumlah siswa yang kurang dari KKM adalah 11 (73,33\%) siswa. Dapat disimpulkan bahwa keterampilan menulis karangan sederhana siswa kelas III SDN Kalipucang Wetan masih rendah. Hal itu terbukti dengan lebih banyaknya siswa yang mendapat nilai di bawah KKM yaitu 11 siswa. Lebih dari setengah siswa yang mengikuti tes awal menulis mendapat nilai yang rendah. Menindaklanjuti permasalahan ini, maka peneliti melaksanakan model pembelajaran kooperatif tipe Picture and Picture berbantu media audio visual berbasis animasi flash untuk meningkatkan keterampilan menulis karangan sederhana siswa kelas III SDN Kalipucang Wetan.

Penilaian menulis karangan sederhana pada siklus I dilaksanakan satu kali yaitu pada akhir pembelajaran pertemuan 2. Hasil keterampilan menulis karangan sederhana pada saat siklus I meningkat dibandingkan hasil keterampilan menulis karangan sederhana pada tahap pra siklus, dimana rata-rata kelas meningkat menjadi 70,33\%. Serta persentase ketuntasan sebanyak 10 (66,7\%) siswa, sedangkan yang belum mencapai KKM sebanyak $5(33,33 \%)$ siswa. hasil menulis karangan sederhana siswa kelas III sudah mengalami peningkatan dibanding pada saat pra siklus. Nilai rata-rata kelas juga mengalami kenaikan yang cukup tinggi pada siklus I. Hasil keterampilan menulis karangan sederhana siswa pada siklus I menunjukkan bahwa melalui model pembelajaran kooperatif tipe Picture and Picture berbantu media audio visual berbasis video animasi flash terjadi peningkatan rata-rata dan jumlah siswa yang mencapai KKM dari kondisi pra siklus. Rata-rata nilai keterampilan menulis karangan sederhana siswa pada siklus I meningkat sebesar 10,32 dari kondisi pra siklus. Rata-rata pada kondisi pra siklus 59,67 dan mengalami peningkatan menjadi 70,33 pada siklus I. Jumlah siswa yang mendapat nilai di atas KKM juga meningkat dibanding kondisi pra siklus. Pada pra siklus jumlah siswa yang mendapat nilai di atas KKM hanya 4 siswa, sedangkan pada saat siklus I sudah mencapai 10 siswa. 
Hasil menulis karangan sederhana siswa kelas III mengalami peningkatan lagi pada saat siklus II. Jumlah siswa yang mencapai KKM dan nilai rata-rata kelas pada siklus II mengalami kenaikan dibanding pada siklus I. Hasil keterampilan menulis karangan sederhana siswa pada siklus II menunjukkan bahwa melalui model pembelajaran kooperatif tipe Picture and Picture berbantu media audio visual berbasis video animasi flash terjadi peningkatan rata-rata dan jumlah siswa yang mencapai KKM dari siklus I dan siklus II. Rata-rata nilai keterampilan menulis karangan sederhana siswa pada siklus II meningkat sebesar 15,67 dari siklus I. Rata-rata pada siklus I adalah 70,33, dan mengalami peningkatan menjadi 86,00 pada siklus II. Jumlah siswa yang mendapat nilai di atas KKM juga meningkat dibanding pada saat siklus I. Pada siklus I jumlah siswa yang mendapat nilai di atas KKM sejumlah 10 siswa, sedangkan pada saat siklus II sudah mencapai 14 siswa. Perbandingan persentase ketuntasan hasil menulis karangan sederhana pada kondisi pra siklus, siklus I, dan siklus II. Persentase siswa yang tuntas atau mencapai KKM meningkat dari pra siklus ke siklus I dan dari siklus I ke siklus II. Peningkatan dari pra siklus ke siklus II sebesar 66,63\%. Pada tes awal saat pra siklus persentase ketuntasan siswa hanya 26,7\% dan meningkat pada siklus II menjadi 90,33\%. Berikut ini adalah perbandingan persentase ketuntasan dari pra siklus hingga siklus II dalam diagram batang.

Pembelajaran menggunakan model pembelajaran kooperatif tipe Picture and Picture berbantu media audio visual berbasis video animasi flash dapat meningkatkan proses pembelajaran dan keterampilan menulis karangan sederhana siswa kelas III SDN Kalipucang Wetan. Pembelajaran menulis karangan sederhana dengan menggunakan model pembelajaran kooperatif tipe Picture and Picture berbantu media audio visual berbasis video animasi flash dilakukan dengan belajar menulis karangan dengan menggunakan gambar seri dan video animasi flash secara bersama-sama dengan anggota kelompok. Setiap siswa mendapat satu bagian gambar dari gambar seri dan diminta untuk menulis satu paragraf karangan berdasarkan gambar tersebut. Setelah menulis secara individu, siswa menggabungkan hasil karangan satu kelompok. Tahap selanjutnya setiap kelompok berdiskusi bersama-sama membahas dan mengoreksi hasil karangan mereka. Setelah dikoreksi bersama, hasil karangan ditulis kembali dengan rapi. Tahap terakhir siswa membacakan bersama-sama hasil karangannya di depan kelas. Tahap pembelajaran tersebut sangat berdampak terhadap proses pembelajaran. model pembelajaran picture and picture berbantu media audio visual berbasis video animasi flash membuat suasana pembelajaran lebih menarik karena dengan adanya model ini siswa lebih tertarik mengikuti pembelajaran karena segala pembelajaran yang bersifat abstrak akan dibuat lebih nyata.

Model picture and picture melatih siswa untuk berpikir logis dan sistematis. Membantu siswa belajar berpikir berdasarkan sudut pandang suatu subjek bahasan dengan memberikan kebebasan siswa beragumen terhadap gambar yang diperlihatkan (Heriyanto, 2014; Susanti \& Kusmariyani, 2017). Selain itu, dapat memunculkan motivasi belajar siswa kearah yang lebih baik. Model pembelajaran picture and picture dapat meningkatkan minat siswa dalam proses pembelajaran (Pangestu et al., 2019). Pembelajaran ini memiliki ciri Aktif, Inovatif, Kreatif, dan Menyenangkan. Pembelajaran picture and picture ini siswa dituntut harus bertanggung jawab atas segala sesuatu yang dikerjakan dalam kelompoknya (Pebriana et al., 2017). Menggunakan alat bantu media gambar tersebut diharapkan siswa dapat mengikuti pelajaran dengan fokus yang baik dan dalam kondisi yang menyenangkan, sehingga apapun pesan yang disampaikan oleh guru, bisa diterima dengan baik dan mampu meresap dalam hati serta dapat diingat kembali oleh siswa (Telussa, 2017). Model pembelajaran picture and picture dalam meningkatkan kemampuan menulis teks recount. Jadi, model pembelajaran picture and picture sangat efektif dalam meningkatkan kemampuan menulis (Widyawati, 2019). Pembelajaran Picture and Picture dapat meningkatkan hasil belajar siswa, tetapi semua itu kembali pada guru, siswa itu sendari jika guru mengajar sesuai dengan tujuan pembelajaran maka akan mendapat hasil yang baik pula, tetapi jika siswanya tidak mendukung hal itu maka tujuan pembelajaran tidak akan tercapai (St. \& Saliadin, 2016). Jika siswa memiliki tingkat intellengensi yang tinggi maka tujuan pembelajaran akan tercapai. Jadi, penerapan model picture and picture akan membuat siswa belajar lebih giat karena siswa dapat melihat dan paham akan materi karena materi yang bersifat abstrak bisa dilihat secara nyata oleh siswa. Selain model pembelajaran media juga bisa digunakan sebagai solusi pembelajaran. dalam penelitian ini media yang digunakan dalam penelitian ini adalah media audio visual berbasis animasi Flash.

Media audio visual yang menampilkan realitas materi dapat memberikan pengalaman nyata pada siswa saat mempelajarinya sehingga mendorong adanya aktivitas diri (Utami et al., 2019). Media audio visual berupa video dapat menyajikan masalah atau materi yang dapat menarik perhatian dan minat siswa dalam mengikuti pembelajaran di dalam kelas (Agustini et al., 2016). Media audio visual memiliki potensi yang cukup besar bila dimanfaatkan sebagai media pembelajaran yang memungkinkan peserta didik akan dapat mengamati secara langsung tentang wujud benda yang sesungguhnya, mengamati proses dari suatu kejadian atau suatu perubahan, mengamati perbedaan warna dan mengamati suatu gerakan dan lain-lain yang diiringi beserta dengan suara (Israwati, 2017). Media audio visual akan membuat siswa 
lebih aktif dan pembelajaran lebih bermakna karena model pembelajaran yang menitikberatkan pada penggunaan masalah di dunia nyata yang melibatkan siswa untuk memecahkan masalah tersebut (Kusumayanti et al., 2017; Paramartha et al., 2016). Media audio visual membantu menampilan fakta atau konsep secara nyata sehingga siswa lebih mudah untuk memahami pembelajaran yang diberikan, dengan pemahaman yang lebih baik maka hasil belajarpun akan lebih baik pula (Windasari \& Sofyan, 2018). Salah satu media audio visual adalah animasi flash.

Media animasi Flash karena Flash merupakan sebuah program yang mampu membuat Animasi mulai dari yang sederhana hingga kompleks (Hartiti, 2014). Media animasi berbasis macromedia flash sudah banyak digunakan untuk meningkatkan hasil belajar dan membuktikan bahwa media animasi dapat meningkatkan hasil belajar kognitif, afektif dan psikomotorik siswa(Abu \& Hamsyah, 2016; Agustina et al., 2017; Sukiyasa \& Sukoco, 2013). Animasi Flash cenderung di buat dengan Adobe Flash atau software yang sejenis. Konsep Animasi flash sangat mirip dengan video, dikarenakan dia terdiri dari urutan gambargambar statis untuk menciptakan ilusi seolah-olah adanya gerakan disaat gambar-gambar tersebut di mainkan secara berurutan dengan sukses. Banyak sekali projek multimedia yang menggunakan film animasi, termasuk Animasi flash, dan software untuk merakit film animasi tersebut. Menggunakan model pembelajaran kooperatif tipe Picture and Picture berbasis video animasi flash tersebut siswa dapat lebih mengembangkan keterampilan menulis siswa. Melalui model Picture and Picture berbasis video animasi flash dapat memudahkan siswa dalam membuat alur suatu karangan. Melalui model pembelajaran kooperatif siswa dapat mengembangkan potensi individu dan dapat pula saling membantu dan bekerjasama dalam kelompok kecil. Oleh karena itu, peneliti ingin bertujuan untuk mengkaji efektivitas model pembelajaran kooperatif tipe Picture and Picture berbasis video animasi flash di kelas III SDN Kalipucang Wetan untuk meningkatkan keterampilan menulis karangan siswa.

\section{Simpulan dan Saran}

Berdasarkan hasil penelitian dan pembahasan, pembelajaran menggunakan model pembelajaran kooperatif tipe Picture and Picture berbantu media audio visual berbasis video animasi flash dapat meningkatkan proses pembelajaran dan keterampilan menulis karangan sederhana siswa kelas III SDN Kalipucang Wetan. Pembelajaran menulis karangan sederhana dengan menggunakan model pembelajaran kooperatif tipe Picture and Picture berbantu media audio visual berbasis video animasi flash dilakukan dengan belajar menulis karangan dengan menggunakan gambar seri dan video animasi flash secara bersama-sama dengan anggota kelompok. Setiap siswa mendapat satu bagian gambar dari gambar seri dan diminta untuk menulis satu paragraf karangan berdasarkan gambar tersebut. Setelah menulis secara individu, siswa menggabungkan hasil karangan satu kelompok. Tahap selanjutnya setiap kelompok berdiskusi bersama-sama membahas dan mengoreksi hasil karangan mereka. Setelah dikoreksi bersama, hasil karangan ditulis kembali dengan rapi. Tahap terakhir siswa membacakan bersama-sama hasil karangannya di depan kelas.

\section{Daftar Rujukan}

Abu, S. H. N., \& Hamsyah, E. F. (2016). Pengaruh Penggunaan Media Pembelajaran Berbasis Macromedia Flash 8 Terhadap Motivasi dan Hasil Belajar Kognitif Peserta didik Kelas VII SMPN 18 Makassar Studi pada Materi Pokok Asam, Basa dan Garam. Jurnal Ilmiah Kimia Dan Pendidikan Kimia, 17(2), $12-18$.

Agustina, M., Sesunan, F., \& Ertikanto, C. (2017). Pengaruh Implementasi Media Pembelajaran Interaktif Berbasis Macromedia Flash Terhadap Hasil Belajar Pada Materi Hukum Newton Tentang Gravitasi. Jurnal Pembelajaran Fisika, 5(5), 11-19.

Agustini, P. P., Kristiantari, M. . R., \& Putra, D. K. N. S. (2016). Penerapan Model Pembelajaran Berbasis Masalah Berbantuan Media Audio Visual Untuk Meningkatkan Hasil Belajar Keterampilan Menyimak Tema Sejarah Peradaban Indonesia Pada Siswa Kelas V Sdn 8 Sumerta. MIMBAR PGSD Undiksha, 4(1). https://doi.org/10.23887/jjpgsd.v4i1.7265.

Ahmad, S. (2016). Pengaruh Model Pembelajaran Langsung Terhadap Kemampuan Menulis Puisi Siswa Kelas X SMA Bina Bersaudara Medan. Jurnal Pendidikan Bahasa Dan Sastra Indonesia, 5(2), 44-59.

Dalman. (2017). Keterampilan Membaca. PT Rajagrafindo Persada.

Hartiti, R. (2014). Penerapan Media Animasi Flash dalam Pembelajaran Motif Batik Siswa Kelas X SMA Negeri 1 Menganti. Jurnal Seni Rupa, 1(1). 
Hasmi, F. (2017). Peningkatan Keterampilan Membaca Permulaan Dengan Menggunakan Media Kartu Kata Pada Siswa Kelas Ii Sd Negeri 001 Rimba Sekampung Dumai. School Education Journal Pgsd Fip Unimed, 7(4), 423-428. https://doi.org/10.24114/sejpgsd.v7i4.8096.

Heriyanto, H. (2014). Penggunaan Model Pembelajaran Picture and Picture Untuk Meningkatkan Kemampuan Siswa Menulis Karangan. PEDAGOGIA: Jurnal Pendidikan, 3(1), 10. https://doi.org/10.21070/pedagogia.v3i1.52.

Israwati. (2017). Kesulitan Guru PAUD Dalam Menggunakan Media Audio Visual Pada Kegiatan Pembelajaran di TK Pertiwi Banda Aceh. Serambi Akademica, V(1), 53-63. http://jurnal.serambimekkah.ac.id/serambi-akademika/article/view/289/271.

Kusumayanti, N. P. C., Asri, I. G. A. A. S., \& Putra, D. K. N. S. (2017). Pengaruh Model Pembelajaran Problem Based Learning Berbantuan Audio Visual Terhadap Kompetensi Pengetahuan IPS Siswa Kelas V. Mimbar PGSD Universitas Pendidikan Ganesha, 5(2), 1-10. https://doi.org/10.23887/jisd.v2i2.15494.

Pangestu, G., Nasution, S. A., \& Efendi, I. (2019). Pengaruh Model Pembelajaran Picture and Picture Terhadap Minat Belajar IPS Siswa. E-Journal Skripsi: Fakultas Keguruan Dan Ilmu Pendidikan, 2(4). https://ojs.unida.ac.id/skripsiunida/article/view/1681.

Paramartha, I. M. D., Suniasih, N. W., \& Negara, I. G. A. O. (2016). Pengaruh Model PBL Berbantuan Media Audio Visual Terhadap Penguasaan Kompetensi Pengetahuan IPA. Mimbar PGSD Undiksha, 4(1), 1-10. https://doi.org/10.23887/jjpgsd.v4i1.7137.

Pebriana, G. R., Dibia, I. K., \& Renda, N. T. (2017). Penerapan Model Pembelajaran Picture and Picture Untuk Meningkatkan Aktivitas dan Hasil Belajar Siswa Kelas V Universitas Pendidikan Ganesa. PGSD Universitas Pendidikan Ganesha, https://ejournal.undiksha.ac.id/index.php/JJPGSD/article/viewFile/9861/6272.

St., K., \& Saliadin, L. (2016). Penerapan Metode Picture and Picture dalam Meningkatkan Hasil Belajar Siswa Kelas V B DI MIN Konawe Selatan Kec. Konda Kab. Konawe selatan. Jurnal Al-Ta'dib, 9(1), 120-143. https://ejournal.iainkendari.ac.id/index.php/al-tadib/article/view/506/492.

Sukiyasa, K., \& Sukoco, S. (2013). Pengaruh media animasi terhadap hasil belajar dan motivasi belajar siswa materi sistem kelistrikan otomotif. Jurnal Pendidikan Vokasi, 3(1), 126-137. https://doi.org/10.21831/jpv.v3i1.1588.

Susanti, P. A., \& Kusmariyani, N. N. (2017). Penerapan Model Picture And Picture Berbasis Pendekatan Saintifik Untuk Meningkatkan Hasil Pengetahuan IPA. Jurnal Ilmiah Sekolah Dasar, 1(2), 99. https://doi.org/10.23887/jisd.v1i2.10144.

Telussa, R. P. (2017). Penerapan Model Pembelajaran Picture And Picture Dalam Meningkatkan Hasil Belajar Sosiologi pada Konsep Mobilitas Sosial Di Pkbm Mekar Sari Kabupaten Nabire Papua. Jurnal Pedagogika Dan Dinamika Pendidikan, 6(1), 1. https://doi.org/doi: https://doi.org/10.30598/pedagogikavol8issue2year2020.

Utami, M. T., Koeswati, H. D., \& Giarti, S. (2019). Model Problem Based Learning ( PBL ) Berbantuan Media audio Visual Untuk Meningkatkan Keteramoilan Berpikir Kritis Pada Siswa Kelas 5 Sekolah Dasar. MAJU, 6(1), 80-91. https://doi.org/https://www.ejournal.stkipbb.

Widyawati, W. Y. (2019). Keefektifan Model Pembelajaran Picture and Picture Dalam Keterampilan Menulis Untuk Tingkat Universitas. KREDO : Jurnal Ilmiah Bahasa Dan Sastra, 2(2), 226-241. https://doi.org/10.24176/kredo.v2i2.3027.

Windasari, T. S., \& Sofyan, H. (2018). Pengaruh Penggunaan Media Audio Visual Terhadap Hasil Belajar IPA Siswa Kelas IV Sekolah Dasar. Jurnal Pendidikan Dasar, 10(4), 6. https://doi.org/DOI: doi.org/10.21009/JPD.0101.01.

Yesica, D., \& Rosmaini. (2017). Efektivitas Model Pembelajaran Berbasis Masalah (Problem Based Learning) Terhadap Kemampuan Memproduksi Teks Deskripsi Pada Siswa Kelas Vii Smp Negeri 9 Medan Tahun Ajaran 2016/ 2017. Basastra, 6(2), 93. https: //doi.org/10.24114/bss.v6i2.6380. 